\title{
Stability Indicating UHPLC Method, Development and Validation for Estimation of Eltrombopag and Related Impurities in Tablet Dosage form
}

\author{
THARLAPU SATYA SANKARSANA JAGAN MOHAN ${ }^{1,2, *}$, \\ KHAGGA MUKKANTI ${ }^{4}$ and HITESH A JOGIA ${ }^{3}$
}

${ }^{1}$ Research \& Development, Jawaharlal Nehru Technological University, Kakinada-533003, India.

${ }^{2}$ Epione Labs Private LTD, Nacharam Industrial Area, Hyderabad-500076, India.

3 Janssen Pharmaceuticals, Jogeshwari (E), Mumbai-400060, India.

${ }^{4}$ Institute of Science \& Technology, Jawaharlal Nehru Technological University,

Kukatpally, Hyderabad-500085, India.

${ }^{*}$ Corresponding author E-mail: victoryjagan1@gmail.com

http://dx.doi.org/10.13005/ojc/340262

(Received: January 01, 2018; Accepted: March 05, 2018)

\section{ABSTRACT}

A novel, agile, mass compatible, stability indicating isocratic method developed by using ultra high performance liquid chromatographic (UHPLC) for estimation of Eltrombopag along with its impurities in tablet formulation. Achieved a good separation on Agilent SB C8 $(50 \times 3.0 \mathrm{~mm}, 1.8 \mu)$ column and mobile phase composed of acetonitrile and $0.1 \%$ glacial acetic acid buffer in the ratio of 60:40 $\mathrm{v} / \mathrm{v}$ at $0.4 \mathrm{ml} /$ minute flow rate and $25^{\circ} \mathrm{C}$ column temperature within runtime of 15 minutes. Eltrombopag was detected at $230 \mathrm{~nm}$. The proposed method proves its stability indicating power by resolving Eltrombopag peak from its process impurities and degradation products with more than resolution 2.0. The proposed method is not only simple but capable to separate its potential degradant. The intended method is efficient to determine assay of Eltrombopag in the existence of its impurities within the same run. The retention time observed for Eltrombopag is about 3.9 minutes. The designed method is validated for precision, accuracy, sensitivity, robustness and specificity parameters according to $\mathrm{ICH}$ guidelines. Eltrombopag was exposed to stress conditions in acidic, basic, thermal, water, oxidative, humidity and photo degradation. Noticeable degradation is observed in oxidative hydrolysis.

Keywords: Eltrombopag, Validation, UHPLC, Stability indicating method, Forced degradation, Methanol.

\section{INTRODUCTION}

Eltrombopag is an approved drug for adult patients suffering from chronic immune thrombocytopenic purpura (ITP). The symptoms are insufficient response to immune globulins, or splenectomy, corticosteroids and having oral bioavailability. Use of Eltrombopag in lower dose is

This is an 2 Open Access article licensed under a Creative Commons Attribution-NonCommercial-ShareAlike 4.0 International License (https://creativecommons.org/licenses/by-nc-sa/4.0/ ), which permits unrestricted NonCommercial use, distribution and reproduction in any medium, provided the original work is properly cited. 
being essential to shorten the bleeding risk by increasing the platelet count and the dose can be adjusted upon the platelet count response. It is also used for thrombocytopenia treatment in patients with hepatitis $C$ virus and chronic liver disease (1-3). Chemically Eltrombopag Olamine is $3^{\prime}-\{(2 Z)-2-[1-$ (3,4-dimethylphenyl)-3-methyl-5-oxo-1,5-dihydro4H-pyrazol-4-ylidene]hydrazino\}-2'-hydroxy-3biphenylcarboxylic acid - 2-aminoethanol (1:2) (Fig. 1) and the molecular weight of Eltrombopag Olamine is 564.65 and 442.5 for Eltrombopag (4). Few analytical methods reported in the literature for the content estimation of Eltrombopag in drug substance, biological samples using high performance liquid chromatography (HPLC) and Mass Spectroscopy (MS) (5-7). There is one more reported method for the Eltrombopag quantification in pharmaceutical bulk and formulations by using ultra performance liquid chromatography (UPLC) (8). The purpose of this research was to develop an assay method which is stability indicating for estimation of Eltrombopag in a pharmaceutical formulations by using ultra high performance liquid chromatography (UHPLC) and separating its degradants along with process related impurities. To the simplest of our information no methodology is accessible in the literature by separating the impurities, 1, 2, 3 (Fig. 1) using only 15 min. runtime.

The objective of stability indicating method is to resolve all the major degradants and potential process related impurities by achieving a proper mass balance during the forced degradation. Stability indicating method is capable to measure the active substance and all its degradation products unequivocally in presence of excipients present in the respective formulation (9). The power of any stability indicating analytical method is to be proved in stress study by identifying its degradation products which in turn establishes the innate stability of the molecule and its degradation pathways (10).

The key objective of the current research was to develop a validated reverse phase UHPLC method which is stability indicating for the quantitative estimation of Eltrombopag and its process impurities and possible degradants during forced degradation. In the current study Eltrombopag, three of its process related impurities are: Impurity-1 (Fig. 1b), Impurity-2 (Fig. 1c) and Impurity-3 (Figure 1d).

\section{MATERIALS AND METHODS}

\section{Chemicals and reagents}

The Eltrombopag active pharmaceutical ingredient and three process related impurities (Impurity-1, Impurity-2 and Impurity-3) and the finished product tablets was gifted by Epione Labs. (Nacharam, Hyderabad, India). Acetonitrile, glacial acetic acid, hydrochloric acid and hydrogen peroxide, sodium hydroxide were procured from Merck \& Co, Germany. Ultra pure water used in this study is collected from Milli-Q plus purification system.

Table 1: System suitability data

\begin{tabular}{lccccc}
\hline Name & RT (min.) & RRT $^{\mathrm{a}}$ & Resolution $^{\mathrm{b}}$ & Tailing Factor & RRF $^{\mathrm{c}}$ \\
\hline Imp-1 & 1.081 & 0.28 & - & 1.3 & 2.11 \\
Eltrombopag & 3.852 & 1.00 & 11.4 & 1.1 & 1.00 \\
Imp-2 & 6.103 & 1.58 & 5.9 & 1.1 & 0.83 \\
Imp-3 & 8.519 & 2.21 & 4.8 & 1.2 & 0.90 \\
\hline
\end{tabular}

a Relative retention times (RRT) were calculated against the retention time (RT) of Eltrombopag.

b Resolution was calculated between two adjacent peaks.

c Relative response factor (RRF) was computed against Eltrombopag peak response. 
<smiles>CCc1cccc(-c2cccc(N/N=C3/C(=O)N(c4ccc(C)c(C)c4)N=C3C)c2O)c1</smiles>

Eltrombopag<smiles>Nc1cccc(-c2cccc(C(=O)O)c2)c1O</smiles>

(b)

(a)<smiles>COC(=O)c1cccc(-c2cccc(NN=C3C(=O)N(c4ccc(C)c(C)c4)N=C3C)c2O)c1</smiles>

(c)<smiles>[H][Y1]1=NN(c2ccc(C)c(C)c2)C(=O)/C1=N/Nc1cccc(-c2cccc(C(=O)O)c2)c1OCC</smiles>

(d)

Figure 1. Chemical Structures of Eltrombopag and all its process impurities $\begin{array}{llll}\text { (a) Eltrombopag } & \text { (b) Imp-1 } & \text { (c) Imp-2 (d) Imp-3 }\end{array}$

\section{Equipment}

An UHPLC system (Make: Shimadzu, Kyoto, Japan) armed with a diode array detector was used. The output signal was processed using Lab solutions software. Samples for thermal stability study were exposed to heat in an oven (Make: Thermolab, India).

\section{Chromatographic conditions}

Final separation was obtained on Agilent SB C8 $50 \times 3.0 \mathrm{~mm}, 1.8 \mu$ column with mobile phase composed of acetonitrile and $0.1 \%$ glacial acetic acid buffer $(1.0 \mathrm{ml}$ of glacial acetic acid in $1 \mathrm{~L}$ of water) in $60: 40 \mathrm{v} / \mathrm{v}$ ratio and filtered with $0.45 \mu \mathrm{m}$ membrane filter. The mobile phase flow rate was kept at $0.4 \mathrm{~mL} / \mathrm{min}$ by maintaining the column temperature at $25^{\circ} \mathrm{C}$, monitored at $230 \mathrm{~nm}$ detector wavelength. Samples were injected for a run time of about $15 \mathrm{~min}$. with an injection volume of $2 \mu \mathrm{L}$. Used methanol as diluent. Calculations were performed by using external standardization methodology.

\section{Standard solution}

Eltrombopag $1000 \mu \mathrm{g} / \mathrm{ml}$ standard stock solution is prepared by dissolving the equivalent amount in diluent.
Further a $0.5 \mu \mathrm{g} / \mathrm{ml}$ of Eltrombopag standard solution was prepared in further dilutions using diluent.

\section{System suitability solution}

Eltrombopag $1000 \mu \mathrm{g} / \mathrm{ml}$ and all impurities $0.5 \mu \mathrm{g} / \mathrm{ml}$ are prepared by dissolving equivalent amount of API and spiking impurities in diluent.

\section{Sample Solution}

Crush 20 Tablets to a fine powder and transferred $100 \mathrm{mg}$ of powder equivalent of Eltrombopag in a $100 \mathrm{~mL}$ volumetric flask. Diluent of $60 \mathrm{~mL}$ was added to it and sonicated for $30 \mathrm{~min}$. with and make up to volume with diluent. Filter the solution using $0.45 \mu \mathrm{m}$ filter.

A spiked sample solution is prepared by spiking all three known impurities at the concentration of $0.5 \%$ with respect to sample concentration of $1000 \mu \mathrm{g} / \mathrm{ml}$.

\section{Method development and Optimization of the chromatographic conditions}

The main objective of the research is to develop a stability indicating method for the separation Eltrombopag and its related compounds by using UHPLC. Several trails were conducted 
during the stability indicating method development using UHPLC for the analysis of Eltrombopag and their related compounds in pharmaceutical tablet formulation. Tried with various compositions of mobile phase which consists of buffer with solvents like acetonitrile and methanol, but the combination of buffer and acetonitrile appeared in a lack of symmetry for Eltrombopag and their related compound peaks. The finest results were obtained in the mobile phase consist of acetonitrile and $0.1 \%$ glacial acetic acid buffer $(1.0 \mathrm{ml}$ of glacial acetic acid in $1 \mathrm{~L}$ of water) in $60: 40 \mathrm{v} / \mathrm{v}$ ration at flow rate of $0.4 \mathrm{~mL} / \mathrm{min}$. using Agilent SB C8 $50 \times 3.0 \mathrm{~mm}, 1.8 \mu$ column, column temperature of $25{ }^{\circ} \mathrm{C}$ using $\mathrm{DAD}$ detector at $230 \mathrm{~nm}$, and able to resolve Eltrombopag and its three impurities (Imp-1 to Imp-3) (Fig. 2) by meeting the system suitability requirement with a resolution of more than 2.0 between all adjacent peaks. Evaluated the response factor for the impurities related to Eltrombopag (Table 1). Using the above chromatographic conditions achieved a good separation with a total runtime of 15 minutes. $\mathrm{mV}$ SST Soln.led

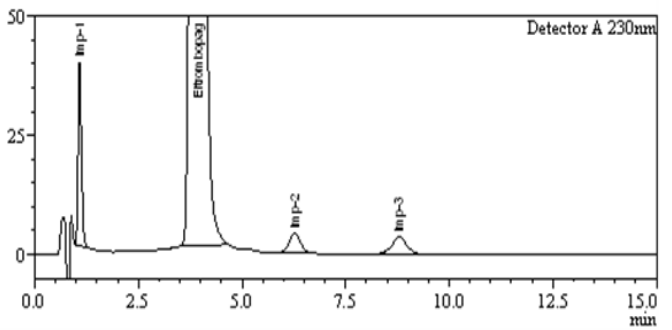

Fig. 2. System suitability solution

Individual solutions of Eltrombopag and its process impurities were scanned in the range of $200 \mathrm{~nm}$ to $400 \mathrm{~nm}$ using a diode array detector. Found that all the compounds are showing maximum absorbance at about $230 \mathrm{~nm}$ and hence $230 \mathrm{~nm}$ was opted for method detection.

\section{RESULTS}

\section{Method validation \\ Specificity and forced degradation studies}

Specificity shows the ability of the method to quantify the response of the analyte in accompany of its degradation products and free from blank and placebo interference. Likely degradation product will be identified in stress degradation studies indicates the stability indicating nature of the method. Stress degradation studies for Eltrombopag tablets were executed under acidic hydrolysis (For $60 \mathrm{~min}$. in $0.1 \mathrm{M} \mathrm{HCl}$ at $60^{\circ} \mathrm{C}$ ), basic hydrolysis (For $60 \mathrm{~min}$. at $60{ }^{\circ} \mathrm{C}$ in $0.1 \mathrm{M} \mathrm{NaOH}$ ), hydrolytic oxidation (For 60 min. in hydrogen peroxide $(10 \%)$ at $60{ }^{\circ} \mathrm{C}$ ), and thermal condition (For $12 \mathrm{~h}$ at $105^{\circ} \mathrm{C}$ ), Refluxed at $60^{\circ} \mathrm{C}$ with water for about 60 minutes. Exposed the samples to humidity study at $25^{\circ} \mathrm{C} / 90 \% \mathrm{RH}$ about 15 days and exposed the sample to light of 200 Watt/hours. The samples prepared in the above conditions were filtered with $0.45 \mu \mathrm{m}$ filter before dilution. Water bath (with temperature controller) was used to carry out the stress degradation studies.

Eltrombopag shows a significant degradation in peroxide oxidation (Fig. 3b). Eltrombopag was degraded into Imp-1, Imp-2 and unknown impurity at RRT about 1.29 by oxidative hydrolysis. The mass balance found to be more than $95 \%$ for the degraded samples in all the stress conditions (Table 2). Verified peak purity for every stress sample solution using HPLC-PDA system and the results found to be passed as per the software acceptance criteria, which demonstrates analyte peak homogeneity (Free from overlapping of peaks).

$\mathrm{mV}$

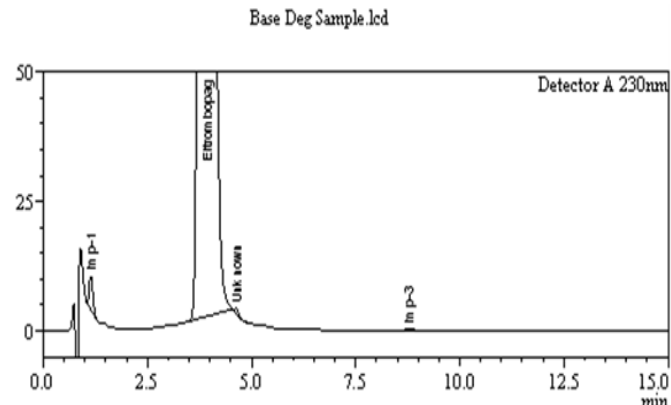

(a)

$\mathrm{mV}$

Peroxide Deg Sample.led

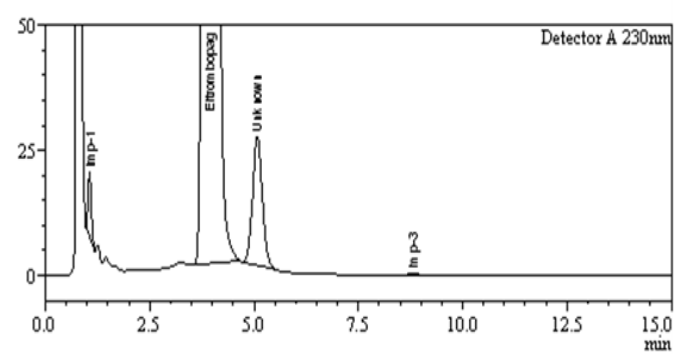

(b)

Fig. 3. Eltrombopag forced degradation chromatograms (a) Base hydrolysis (b) Peroxide oxidation 
Table 2: Stress degradation data of Eltrombopag

\begin{tabular}{|c|c|c|c|}
\hline Stress Condition & $\%$ Degradation & Mass Balance & Peak purity index \\
\hline Acid (For $60 \mathrm{~min}$. in $0.1 \mathrm{M} \mathrm{HCl}$ at $60^{\circ} \mathrm{C}$ ) & 0.04 & 99.6 & 1.000 \\
\hline Base (For $60 \mathrm{~min}$. in $0.1 \mathrm{M} \mathrm{NaOH}$ at $60^{\circ} \mathrm{C}$ ) & 0.14 & 98.7 & 1.000 \\
\hline Peroxide (For 60 min. in $\mathrm{H}_{2} \mathrm{O}_{2}(10 \%)$ at $60{ }^{\circ} \mathrm{C}$ ) & 2.23 & 98.6 & 1.000 \\
\hline Water (at $\left.60{ }^{\circ} \mathrm{C}, 60 \mathrm{~min}.\right)$ & 0.05 & 99.5 & 1.000 \\
\hline Thermal (For $12 \mathrm{~h}$ at $105^{\circ} \mathrm{C}$ ) & 0.05 & 99.5 & 1.000 \\
\hline Humidity (For 15 Days at $25^{\circ} \mathrm{C}$ and $90 \% \mathrm{RH}$ ) & 0.05 & 100.0 & 1.000 \\
\hline Light (200 Watt/h) & 0.04 & 98.8 & 1.000 \\
\hline
\end{tabular}

a Mass Balance $=\%$ Degradation $+\%$ Assay

\section{Precision}

Precision study for the intended method was assessed by injecting Eltrombopag sample along with $0.5 \%$ level of its three impurities $(0.5 \%$ of impurity concentration with respect to $1000 \mathrm{mg} /$ $\mathrm{mL}$ Eltrombopag) on six individual samples. The percent RSD of spiked Impurities 1, 2, and 3 are less than $5 \%$, proves good method precision (Table 3).

\section{Linearity}

Linearity of the method was established by preparing a series of six concentrations (i.e., LOQ, 10, 20, 40, 100, and 200\%) with $1.0 \%$ thought of to be $100 \%$ by linear least square analysis method. Correlation coefficient (r), slope and yintercept for the three impurities are presented in Table 3. The obtained correlation coefficient is more than 0.999, for all impurities indicating a linear response of the method.

Table 3: Regression and precision data for Eltrombopag

\begin{tabular}{lcccccc}
\hline Compound & $\begin{array}{c}\text { LOD } \\
(\%)\end{array}$ & $\begin{array}{c}\text { LOQ } \\
(\%)\end{array}$ & Slope (b) & Intercept (a) & $\begin{array}{c}\text { Precision } \\
(\% R S D)\end{array}$ & $\begin{array}{c}\text { LOQ Precision } \\
(\% R S D)\end{array}$ \\
\hline Imp-1 & 0.001 & 0.010 & 404897 & -9088 & 1.0 & 7.0 \\
Eltrombopag & 0.018 & 0.020 & 191735 & 2850 & 0.9 & 4.4 \\
Imp-2 & 0.013 & 0.038 & 158891 & 1500 & 0.6 & 6.5 \\
Imp-3 & 0.012 & 0.035 & 172570 & -303 & 0.8 & 7.0 \\
\hline
\end{tabular}

\section{Limit of Quantification (LOQ) and Limit of Detection (LOD)}

The LOQ and the LOD for all the three process impurities of Eltrombopag were assessed at the concentrations where the signal-to-noise ratios detected were $3: 1$ ratio and 10:1 ratio, respectively. LOQ level precision was also determined by analysing six individual consecutive preparations of the three process impurities by calculating the RSD (\%) (Table 3).

\section{Accuracy}

For all the three impurities the percentage recovery in triplicate was determined for all the three impurities at $0.5,1.0$, and $1.5 \%$ levels with respect to Eltrombopag concentration $(1000 \mathrm{mg} / \mathrm{mL})$ (Table 4).

\section{Robustness}

Robustness determines the capability of the method to remain unchanged by small planned variations in the method parameters. The conditions studied were flow rate (altered by $\pm 0.05 \mathrm{~mL} / \mathrm{min}$.), column temperature (altered by $\pm 5^{\circ} \mathrm{C}$ ) and organic phase variation (altered by $\pm 10 \%$ ). Resolution between adjacent peaks is more than 2.0 in all the conditions (Table 5).

\section{Solution stability}

Standard and test solutions stability were verified by keeping them on benchtop for 48 hours. Both the solutions are found to be stable at benchtop and no significant change was observed for all the three impurities. 
Table 4: Accuracy $(n=3)$ data for Eltrombopag

\begin{tabular}{lcccc}
\hline Level & $\begin{array}{c}\text { Imp-1 } \\
(\% R S D)\end{array}$ & $\begin{array}{c}\text { Imp-2 } \\
(\% R S D)\end{array}$ & $\begin{array}{c}\text { Imp-3 } \\
(\% R S D)\end{array}$ & $\begin{array}{c}\text { Eltrombopag } \\
(\% R S D)\end{array}$ \\
\hline $50 \%$ & $104.8(1.6)$ & $100.3(0.5)$ & $105.0(2.4)$ & $101.5(0.9)$ \\
$100 \%$ & $106.6(0.6)$ & $102.3(1.2)$ & $100.9(1.5)$ & $100.8(0.9)$ \\
$150 \%$ & $103.7(3.3)$ & $100.4(4.0)$ & $98.1(3.0)$ & $102.1(0.6)$ \\
\hline
\end{tabular}

Table 5: Robustness data

\begin{tabular}{|c|c|c|c|c|c|c|}
\hline Resolution $^{a}$ & $0.35 \mathrm{ml} / \mathrm{min}$. & $0.45 \mathrm{ml} / \mathrm{min}$ & $20^{\circ} \mathrm{C}$ & $30^{\circ} \mathrm{C}$ & $90 \%$ ACN & $110 \% \mathrm{ACN}$ \\
\hline Imp-1 & - & - & - & - & - & - \\
\hline Eltrombopag & 10.0 & 10.8 & 11.3 & 11.4 & 10.0 & 7.9 \\
\hline Imp-2 & 4.5 & 5.4 & 5.3 & 5.4 & 5.4 & 4.2 \\
\hline Imp-3 & 3.4 & 4.2 & 4.0 & 4.2 & 4.2 & 3.0 \\
\hline
\end{tabular}

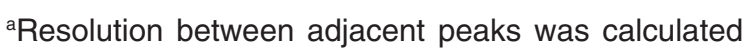

\section{CONCLUSION}

An easy, specific, reliable and mass compatible isocratic method using UHPLC-DAD was developed for the quantitative estimation of Eltrombopag in Tablet formulation. This was the first method for separation and quantification of Eltrombopag and its process related impurities in comparison with reported methodologies. The current method was successfully resolved all the degradants, three known impurities and estimate the active component perfectly. Validated the developed method according to $\mathrm{ICH}$ guidelines and found to be specific, linear, accurate, robust, precise, and rugged. Proposed chromatographic method with a short run time of $15 \mathrm{~min}$. permits the analysis of a many samples in a day. The developed methodology has proved the stability-indicating power, and hence it can be used for regular analysis throughout stability studies in quality control laboratories.

\section{ACKNOWLEDGMENT}

The authors are grateful to the management of Epione Labs. Pvt. Ltd. for their support. Authors wish to acknowledge the research group for providing the samples for our research.

\section{REFERENCES}

1. Deng, Y.; Madatian, A.; Wire, M.B.; Bowen, C.; Park, J.W.; Williams, D.; Peng, B.; Schubert, E.; Gorycki, F.; Levy, M.; Gorycki, P.D. Metabolism and disposition of eltrombopag, an oral, non peptide thrombopoietin receptor agonist, in healthy human subjects, Drug Metab Dispos., 2011, 39(9), 1734-1746.
2. Serebruany, V.L.; Eisert, C.; Sabaeva, E.; Makarov, L. Eltrombopag (Promacta), a thrombopoietin receptor agonist for the treatment of thrombocytopenia: current and future considerations, Am. J. Ther, 2010., 17(1), 68-74.

3. Allred, A.J.; Bowen, C.J.; Park, J.W.; Peng, B.; 
Williams, D.D.; Wire, M.B.; Lee, E. Eltrombopag increases plasma rosuvastatin exposure in healthy volunteers, $\mathrm{Br}$. J. Clin. Pharmacol., 2011, 72(2), 321-329.

4. https://www.pharma.us.novartis.com/sites/ www.pharma.us.novartis.com/files/ promacta. pdf (accessed Jan 1, 2018).

5. Wire, M.B.; Mclean, H.B.; Pendry, C.; Theodore, D.; Park, J.W.; Peng, B. Assessment of the pharmacokinetic interaction between eltrombopag andlopinavir-ritonavir in healthy adult subjects, Antimicrob. Agents Chemother., 2012, 56(6), 2846-2851.

6. Williams, D.D.; Peng, B.; Bailey, C.K.; Wire, M.B.; Deng, Y.; Park, J.W.; Collins, D.A.; Kapsi, S.G.; Jenkins, J.M. Effects of food and antacids on the pharmacokinetics of eltrombopag in healthy adult subjects: two single-dose, open-label, randomizedsequence, crossover studies, Clin. Ther., 2009, 31(4), 764-776.

7. Rambabu, M.; Ramakrishna, G.; Nageswara,
R.P.; Sridhar, S.; Srinubabu, M.; Ajitha, M. Liquid chromatography-tandem mass spectrometric assay for eltrombopag in 50 $\mu \mathrm{L}$ of human plasma: A pharmacokinetic study, J. of Pharm. and Biomed. Ana., 2014, 98, 68-73.

8. Mahaboob, B.D.; Venkata, R.G.; Shobha, R.T.; Susithra, E.; Rajasekhar, C. RP-UPLC-MS assay method for eltrombopag: Application in pharmaceuticals, human plasma and urine samples, Asian J. Chem, 2015, 27(12), 4615-4619.

9. Monika, B.; Saranjit, S. Development of validated stability indicating assay methodscritical review; J. of Pharm. and Biomed. Ana, 2002, 28, 1011-1040.

10. $\mathrm{ICH}$ harmonized tripartite guideline, stability testing of new drug substances and products, Q1A (R2), 2003.

11. $\mathrm{ICH}$ of technical requirements for the registration of pharmaceutical for the human use, validation of analytical procedures: text and methodology, ICH, Q2 (R1), 2005. 